\section{Hepatitis A seroprevalence in public school children in Campos dos Goytacazes, Rio de Janeiro State, Brazil, prior to the introduction of the hepatitis A universal childhood vaccination}

\author{
Soroprevalência da hepatite $A$ em crianças de escolas \\ públicas em Campos dos Goytacazes, Rio de \\ Janeiro, Brasil, antes da introdução da \\ vacinação infantil universal
}

Seroprevalencia de la hepatitis A en niños de escuelas públicas en Campos dos Goytacazes, Río de Janeiro, Brasil, antes de la introducción de la vacunación infantil universal
Charbell Miguel Kury 1,2,3

Marcelo Alves Pinto 4

Jaquelline Pereira da Silva ${ }^{3}$

Oswaldo Gonçalves Cruz 5

Claudia Lamarca Vitral 3

doi: 10.1590/0102-311X00175614

\begin{abstract}
This cross-sectional study was carried out between August 2011 and July 2012 in the city of Campos dos Goytacazes in Rio de Janeiro State, Brazil. Dried blood spot samples were collected on filter paper from 919 individuals between the ages of 1 and 19 and were tested for antibodies against the hepatitis A virus (anti-HAV). The total prevalence was $20.7 \%$, while 94.7\% of children under the age of 5 were found to be susceptible to HAV infection. The prevalence of anti-HAV increased with age, reaching 33.3\% among individuals aged between 15 and 19, thereby indicating that this municipality has a low level of endemicity for hepatitis A. Age, non-white skin color, accustomed to swimming in the river and more than five people living at home were the factors that were associated with an increase in the chance of a positive anti-HAV result. Mother's education level (secondary or tertiary) was considered a protective factor for HAV infection. The data obtained showed that a large proportion of the children from Campos dos Goytacazes were at risk of HAV infection, which should be minimized with the introduction of the vaccination program against hepatitis $A$ that was launched in the municipality in 2011.
\end{abstract}

Hepatitis A; Hepatitis A Vaccines; Seroepidemiologic Studies
1 Secretaria Municipal de Saúde, Campos do Goytacazes, Brasil. 2 Faculdade de Medicina de Campos, Campos dos Goytacazes, Brasil. 3 Instituto Biomédico, Universidade Federal Fluminense, Niterói, Brasil 4 Instituto Oswaldo Cruz, Fundação Oswaldo Cruz Rio de Janeiro, Brasil. 5 Programa de Computação Científica, Fundação Oswaldo Cruz, Rio de Janeiro, Brasil.

\author{
Correspondence \\ C. L. Vitral \\ Departamento de \\ Microbiologia e Parasitologia, \\ Instituto Biomédico, \\ Universidade Federal \\ Fluminense. \\ Rua Prof. Hernani Melo 101 \\ Niterói, RJ 24210-130, Brasil. \\ clvitral@id.uff.br
}


Susceptibility to infection from the hepatitis A virus (HAV) has increased worldwide. Vaccination has become necessary since unprotected individuals were not infected by the virus in childhood, as in the past. The Strategic Advisory Group on Immunization of the World Health Organization (WHO) supports the integration of the hepatitis A vaccine in immunization programs if properly backed up by data on the impact of the disease in the country and the change of its epidemiological profile, thereby assessing its economic viability 1 . In some countries, including the United States, Israel, China, Argentina, Panama and Uruguay, as well as in certain regions of Spain and Italy, the HAV vaccine is now included in routine childhood immunization programs. The effects of these vaccination programs are confirmed by a substantial reduction in HAV incidence, outbreaks, mortality rates and hospitalization 2. However, it is known that any implementation strategy of a vaccination program for hepatitis A should take into account factors such as level of endemicity, local socioeconomic development, local sanitation conditions and risks of outbreaks.

Serosurveys based on anti-HAV antibodies detection represent one of the main sources of information used for estimating the burden of disease associated with HAV infection. Such studies enable indirect estimates of age-specific incidence rates of infection and are currently the best way to present the situation of hepatitis A in a country ${ }^{3}$. The seroprevalence by age offers a measure of susceptibility of different age groups to new infections and it is useful to understand the concept of transition and risk shift to older age groups that were not infected in childhood.

In Brazil, seroprevalence studies conducted recently mainly in urban areas, showed a consistent decrease of the incidence rates in childhood $4,5,6,7,8,9,10$. Decrease in HAV circulation $8,9,11,12$ as well as a progressive decline in fatal cases related to HAV infection in all Brazilian regions 8 have also begun to be noticed. According to the Brazilian Surveillance System, there is an apparent downward trend in the number of hepatitis A cases reported along the years. The disease rate fell from 11.7 cases per 100,000 in the population in 2005 to 3.1 cases per 100,000 in 201213 . Indeed, while Brazil was formerly recognized as an endemic country for hepatitis A, it is now presenting two distinct epidemiological patterns: intermediate endemicity of hepatitis A in the North, Northeast and Central regions, and low endemicity in the South and Southeast regions $14,15,16$. Recently, force of infection of estimates of hepatitis A stratified by age and endemicity levels based on a primary dataset from the $\mathrm{Bra}$ - zilian National Hepatitis Survey also showed that there is a shift of risk of HAV infection to older age groups 17. This transition in the epidemiological pattern can be worrisome, since the delay in the age of exposure does not subsequently eliminate the risk of infection. From a public health perspective, it is important to identify such epidemiological shifts since the severity of the disease increases with age, determining increased disease burden in older groups. For example, HAV infection has become a leading cause of fulminant hepatic failure (FHF) in Brazil 18, as well as in countries that are experimenting transition in hepatitis A endemicity, such as Argentina 19, India 20, and the Republic of Korea 21. After the implementation of regular immunization against hepatitis A for all children aged 12 months in Argentina in 2005, neither FHF nor liver transplantation due to HAV infection have been observed since 200722 . Together, these facts point out the importance of the implementation of preventive measures through vaccination programs for controlling hepatitis A in Brazil.

Although many seroprevalence studies have been conducted in several Brazilian regions, few were carried out using representative population samples 4,11 . The current study attempted to collect epidemiological data on HAV epidemiology among children and adolescents enrolled in public schools within the educational network of Campos dos Goytacazes, a city located in the Southeastern region of Brazil. In 2011, this municipality was the first to implement hepatitis A vaccination as part of the routine childhood immunization program and it is offered to all children between 1 and 2 years of age, over a 0-6 months schedule. The inclusion of the hepatitis A vaccine in the immunization program was a decision made by this municipality with the aim of prioritizing improved vaccine support for local citizens ${ }^{23}$. The vaccine contains 720 U.EL./ $0.5 \mathrm{~mL}$ of inactivated hepatitis A antigen adsorbed to aluminum hydroxide (child dose) administered intramuscularly. Since its implementation, 30,000 children have been immunized against hepatitis A 24. Results from this study will make it possible to draw conclusions about the future impact that immunization will bring to the epidemiology of hepatitis A in this county.

\section{Methodology}

\section{Study area}

Campos dos Goytacazes is the largest municipal jurisdiction in the state of Rio de Janeiro, Brazil, covering an area of $4,026 \mathrm{~km}^{2}$, with an estimat- 
ed population of 463,731 inhabitants (Brazilian Institute of Geography and Statitics. @Cidades. Campos dos Goytacazes. http://cod.ibge.gov.br/ DC0, accessed on 27/Oct/2015). Economic activity is mainly supported by petroleum extraction, which represents $80 \%$ of all Brazilian production.

According to a recent study conducted by the Trata Brasil Institute 25 for evaluating sanitation in the 100 largest Brazilian municipalities using the National Sanitation Information System (SNIS) database, $90.3 \%$ of citizens from Campos dos Goytacazes have access to a mains water supply and $67.3 \%$ to the sewage system. This data ranks the municipality in fourth position in terms of sanitation coverage among the 10 municipalities of the State of Rio de Janeiro with more than 260,000 inhabitants.

\section{Study design and subjects}

This cross-sectional seroprevalence study of HAV infection was conducted between August, 2011 and July, 2012 among school children and adolescents aged 1 to 19. Three districts from the municipality of Campos dos Goytacazes were selected for the study. The defined geographical areas were urban (Campos), suburban (Guarus), and rural (Baixada Campista) (Figure 1). According to the last demographic census (Brazilian Institute of Geography and Statitics. @Cidades.
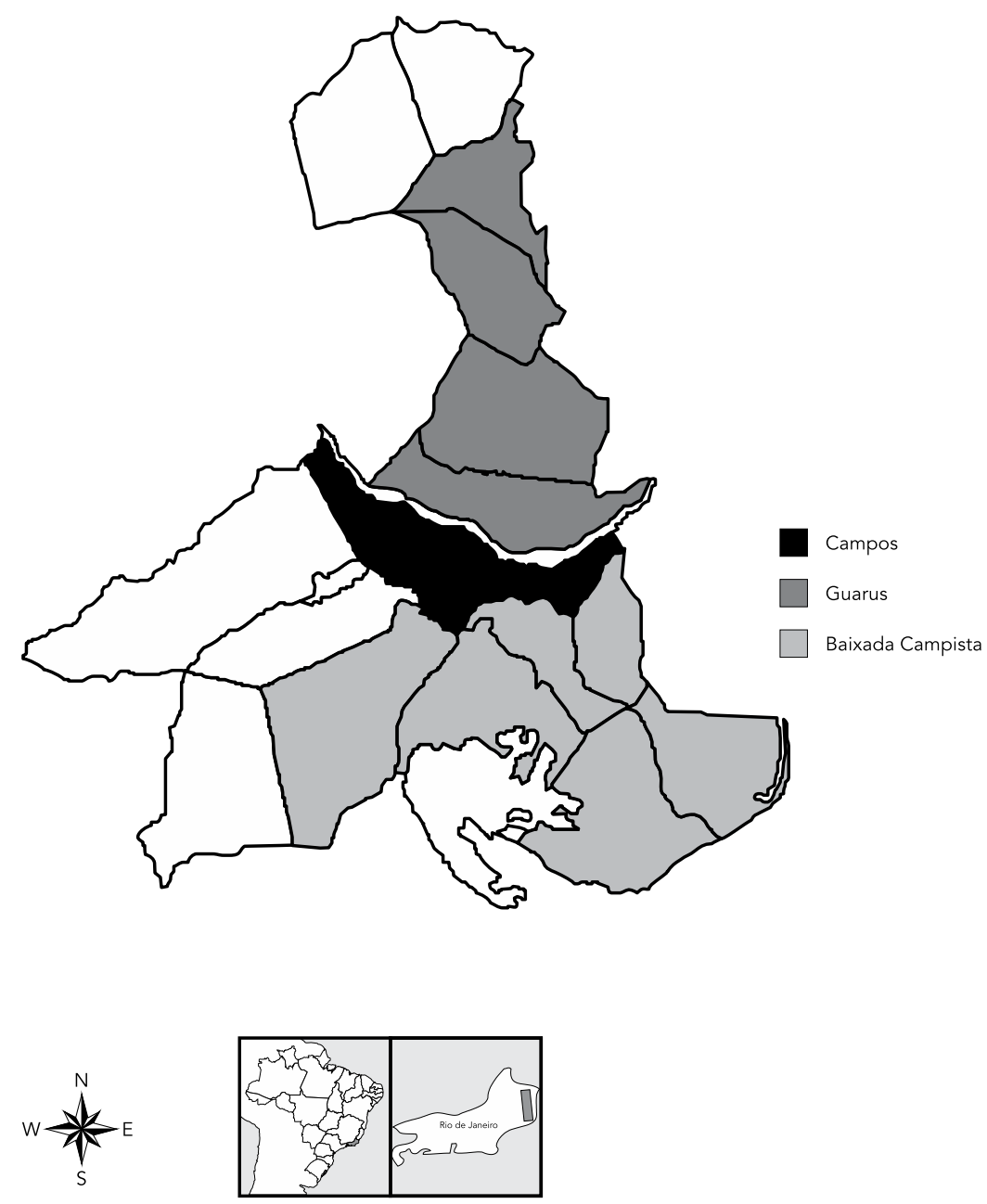
Campos dos Goytacazes. http://cod.ibge.gov.br/ DC0, accessed on 27/Oct/2015), these three districts have a population of over 437,767 inhabitants (91.7\% of municipality residents). Of this total, 140,975 were aged between 1 and 19. The study was carried out with random samples from public daycare facilities and elementary/intermediate schools. In each school a classroom was also sampled randomly. The classroom chosen in each school was visited by a group of health agents from the local Municipal Health Department who invited children or their guardians to participate in the research. On the day of sample collection, individuals who agreed to participate were included in the study. Table 1 shows the number of children registered in public schools and day care centers in the municipality of Campos dos Goytacazes and the number of unregistered children plus those registered in private schools according to the age groups evaluated in this study.

Calculation of sample size was based on a $40 \%$ HAV estimated seroprevalence 14 , with a $5 \%$ precision rate and a 99\% confidence level. The formula for sample size determination (http:// www.openepi.com) yielded a total of 1,033 participants.

\section{Data collection}

Individuals aged between 1 and 19, living in the city of Campos dos Goytacazes, enrolled regularly in public schools and day care centers and showing no record of vaccination against hepatitis A registered in their vaccination card were included in the survey. All participants or guardians were interviewed by trained health personnel using a structured questionnaire. So- ciodemographic data which are thought to have a negative or a positive influence over anti-HAV seropositivity were collected. Participants were clustered in four age groups: 1-4 years, 5-9 years, 10-14 years, and 15-19 years.

\section{Laboratory assays}

A dried blood spot (DBS) sample was obtained from each subject enrolled in the study and further processed and assayed for total antibodies against HAV (anti-HAV) using a commercial enzyme immunoassay (Anti-HAV SYM, Symbiosis, Brazil) following the methodology previously described by Melgaço et al. 26 .

\section{Statistical analysis}

Multiple logistic regression was used to determine the independent effects on associations between anti-HAV positivity and explanatory variables, estimating adjusted odds ratio and 95\% confidence intervals (95\%CI) through selection of the better AIC (Akaike information criterion). In the initial logistic model, all variables $(\mathrm{p}<0.05)$ associated with the seropositivity in univariate analysis were included. Variables with statistically significant associations with anti-HAV positivity were kept in the final model. To take account for the sample we included the design effect using each school as a cluster and the weight proportional to the inverse of number of children in that school. All models used that survey design. Analyses were performed using $\mathrm{R}$ version 3.2 (The R Foundation for Statistical Computing, Vienna, Austria; http://www.r-project.org/) and the survey library.

Table 1

Number of registered and unregistered children in public and private schools in the municipality of Campos dos Goytacazes, Rio de Janeiro State, Brazil.

\begin{tabular}{lccc}
\hline Age group (years) & $\mathbf{n}$ & $\begin{array}{c}\text { Number of children } \\
\text { registered in public } \\
\text { schools }\end{array}$ & $\begin{array}{c}\text { Number of children } \\
\text { excluded from the study * }\end{array}$ \\
\hline $1-4$ & 25,710 & 8,437 & 17,273 \\
$5-9$ & 34,984 & 19,343 & 15,641 \\
$10-14$ & 40,306 & 24,766 & 15,540 \\
$15-19$ & 39,975 & 23,612 & 16,363 \\
Total & 140,975 & 76,158 & 64,817 \\
\hline
\end{tabular}

* Number of unregistered children plus those registered in private schools. 


\section{Ethics}

The study was conducted in line with the provisions of the Declaration of Helsinki. Approval of the study protocol was obtained from the Ethical Research Committee of the Medical Faculty of Campos dos Goytacazes (protocol number 407198). Written informed consent was obtained from all subjects (consent was granted by underage individuals by their parents/guardians) prior to conducting any study or specific procedure.

\section{Results}

A total of 919 subjects aged 1-19 (mean age $8.4 \pm$ 4) were tested for the presence of anti-HAV; the participation rate was of $90 \%$. Exclusion from the study occurred for one or more of the following reasons: history of hepatitis A vaccination, consent form not signed, resident of another municipality or insufficient samples.

The majority of the participants were female $(57.9 \%)$, self-declared non-white $(70.7 \%)$, with low socioeconomic status based on family income $(87.9 \%)$. Parents with a low level of education were also in the majority $(72.6 \%$ of fathers and $63.6 \%$ of mothers were illiterate or had basic levels of education). Families were at most made up of five or less than five members (77\%), with up to two siblings $(69.1 \%)$. The majority of participants lived in urban or suburban areas $(62.1 \%)$ in households with access to piped water $(77.1 \%)$ and a sewage system $(57.9 \%)$, and reported the use of filtered water for consumption (75.5\%). $21.8 \%$ of participants reported a history of contact with flood water and $48.3 \%$ the habit of swimming in rivers. Most of the participants $(81 \%)$ had no record of hepatitis A cases in the family.

The overall prevalence for anti-HAV was $20.7 \%$ and was significantly correlated with age (Table 2). Prevalence in children aged 1-4 was $5.3 \%$ and increased to $18.7 \%$ among those aged 5-9 (OR $=3.60$, 95\%CI: $1.53-8.46)$. From that point on, there was a slight increase in anti-HAV prevalence to $28.3 \%$ in children aged $10-14(\mathrm{OR}=$ 7.87, 95\%CI: $3.30-18.78$ ) and to $33.3 \%$ among those aged 15-19 (OR = 13.47, 95\%CI: 4.04-44.86). The seroprevalence rate was substantially higher among adolescents aged 15-19 years (33.3\%) compared with those in preschool or schoolchildren aged 1-14 (20.1\%), which is consistent with most of the enterically transmitted diseases occurring in early childhood.

As well as age, HAV seroprevalence was also associated with other variables including skin color, level of mothers' education, number of

Prevalence of HAV antibodies according to individual and household-level risk factors. Municipality of Campos dos Goytacazes, Rio de Janeiro State, Brazil, 2011-2012.

\begin{tabular}{|c|c|c|c|c|}
\hline Variable & $\mathrm{n} / \mathrm{N}$ & $\begin{array}{c}\text { Anti-HAV } \\
\text { prevalence (\%) }\end{array}$ & $\begin{array}{c}\text { OR } \\
(95 \% \mathrm{Cl})\end{array}$ & $p$-value \\
\hline \multicolumn{5}{|l|}{ Age group (years) } \\
\hline $1-4$ & $7 / 132$ & 5.3 & 1.00 & - \\
\hline $5-9$ & $81 / 433$ & 18.7 & $3.59(1.53-8.46)$ & 0.0035 \\
\hline $10-14$ & $89 / 315$ & 28.3 & 7.87 (3.30-18.78) & 0.0000 \\
\hline $15-19$ & $13 / 39$ & 33.3 & $13.44(4.04-44.86)$ & 0.0000 \\
\hline \multicolumn{5}{|l|}{ Skin color } \\
\hline White & $34 / 269$ & 12.6 & 1.00 & - \\
\hline Non-white & $156 / 650$ & 24.0 & $2.20(1.32-3.64)$ & 0.0024 \\
\hline \multicolumn{5}{|l|}{ Gender } \\
\hline Female & $116 / 532$ & 21.8 & 1.00 & - \\
\hline Male & $74 / 387$ & 19.1 & $0.77(0.50-1.17)$ & 0.2149 \\
\hline \multicolumn{5}{|l|}{ Family income (MW) * } \\
\hline$\leq 1$ & $100 / 450$ & 22.2 & 1.00 & - \\
\hline$>1$ & $73 / 397$ & 18.4 & $0.94(0.62-1.44)$ & 0.6939 \\
\hline Uncertain/Unknown & $17 / 72$ & 23.6 & $0.86(0.42-1.79)$ & 0.6996 \\
\hline
\end{tabular}

(continues) 
Table 2 (continued)

\begin{tabular}{|c|c|c|c|c|}
\hline Variable & $n / N$ & $\begin{array}{c}\text { Anti-HAV } \\
\text { prevalence (\%) }\end{array}$ & $\begin{array}{c}\text { OR } \\
(95 \% \mathrm{Cl})\end{array}$ & $\mathrm{p}$-value \\
\hline \multicolumn{5}{|l|}{ Level of mother's education } \\
\hline Illiterate & $17 / 60$ & 28.3 & 1.00 & - \\
\hline Primary & $123 / 524$ & 23.5 & $0.62(0.30-1.28)$ & 0.1950 \\
\hline Secondary and higher & $35 / 273$ & 12.8 & $0.31(0.14-0.70)$ & 0.0049 \\
\hline Uncertain/Unknown & $15 / 62$ & 24.2 & $0.84(0.33-2.17)$ & 0.7229 \\
\hline \multicolumn{5}{|l|}{ Level of father's education } \\
\hline Illiterate & $19 / 71$ & 26.8 & 1.00 & - \\
\hline Primary & $131 / 596$ & 22.0 & $0.78(0.40-1.54)$ & 0.4778 \\
\hline Secondary and higher & $26 / 180$ & 14.4 & $0.50(0.22-1.13)$ & 0.0944 \\
\hline Uncertain/Unknown & $14 / 72$ & 19.4 & $1.04(0.43-2.60)$ & 0.9269 \\
\hline \multicolumn{5}{|l|}{ Number of people in the } \\
\hline \multicolumn{5}{|l|}{ household } \\
\hline$\leq 5$ & $120 / 708$ & 16.9 & 1.00 & - \\
\hline$>5$ & $70 / 211$ & 33.2 & $2.56(1.64-4.00)$ & 0.0000 \\
\hline \multicolumn{5}{|l|}{ Number of siblings } \\
\hline$\leq 2$ & $130 / 635$ & 20.5 & 1.00 & - \\
\hline$>2$ & $53 / 248$ & 21.4 & $0.96(0.61-1.50)$ & 0.8458 \\
\hline Uncertain/Unknown & $7 / 36$ & 19.4 & $0.77(0.23-2.56)$ & 0.6647 \\
\hline \multicolumn{5}{|l|}{ Living area } \\
\hline Urban & $55 / 307$ & 17.9 & 1.00 & - \\
\hline Suburban & $55 / 264$ & 20.8 & $0.55(0.32-0.95)$ & 0.0325 \\
\hline Rural & $80 / 348$ & 23.0 & $1.04(0.64-1.71)$ & 0.8633 \\
\hline \multicolumn{5}{|l|}{ Sewage disposal } \\
\hline Public sewer system & $111 / 532$ & 20.9 & 1.00 & - \\
\hline Septic cesspool & $66 / 288$ & 22.9 & $1.36(0.87-2.13)$ & 0.1746 \\
\hline Other & $13 / 99$ & 13.1 & $0.47(0.21-1.04)$ & 0.0623 \\
\hline \multicolumn{5}{|l|}{ Water supply } \\
\hline Piped water & $154 / 709$ & 21.7 & 1.00 & - \\
\hline Artesian well & $24 / 146$ & 16.4 & $0.59(0.32-1.11)$ & 0.1034 \\
\hline Others & $12 / 64$ & 18.8 & $0.39(0.18-0.84)$ & 0.017 \\
\hline \multicolumn{5}{|l|}{ Use of filtered water } \\
\hline Yes & $132 / 694$ & 19.0 & 1.00 & - \\
\hline No & $58 / 225$ & 25.8 & $1.15(0.74-1.80)$ & 0.5385 \\
\hline \multicolumn{5}{|l|}{ Contact with flooding water } \\
\hline No & $135 / 719$ & 8.8 & 1.00 & - \\
\hline Yes & $55 / 200$ & 27.5 & $1.39(0.89-2.18)$ & 0.1535 \\
\hline \multicolumn{5}{|l|}{ Swimming in the river } \\
\hline No & $86 / 475$ & 18.1 & 1.00 & - \\
\hline Yes & $104 / 444$ & 23.4 & $1.53(1.01-2.34)$ & 0.0478 \\
\hline \multicolumn{5}{|c|}{ Hepatitis A cases in the family } \\
\hline No & $154 / 744$ & 20.7 & 1.00 & - \\
\hline Yes & $16 / 84$ & 19.0 & $0.83(0.37-1.83)$ & 0.6387 \\
\hline Uncertain/Unknown & $20 / 91$ & 22.0 & $0.89(0.41-1.96)$ & 0.7772 \\
\hline
\end{tabular}

95\% Cl: 95\% confidence interval; $\mathrm{HAV}$ : hepatitis A virus; $\mathrm{MW}$ : minimum wage; $\mathrm{n} / \mathrm{N}$ : number of positives out of the number tested; OR: odds ratio.

* MW in Brazil, 2015 (US\$ 197). 
household members, location of the household, water supply, and habit of swimming in rivers (Table 2). After adjustment for confounding covariates by using two-level logistic regression analysis, increasing age, non-white skin color, habit of swimming in rivers, number of household members $>5$, and level of mother's education emerged as significant ( $\mathrm{p}<0.05$ ) independent predictors of HAV seropositivity (Table 3 and Figure 2).

\section{Discussion}

This seroepidemiological study was conducted in the first Brazilian municipality that implemented hepatitis A universal childhood immunization in 2011, prior to the inclusion of hepatitis A vaccine in the Brazilian Expanded Program of Immunization (EPI). Results showed that only $5.3 \%$ of children under the age of five were immune to HAV after natural infection. Anti-HAV prevalence increased with age, but did not exceed 33.3\% among those aged 15-19. Levels of HAV endemicity were classified on the basis of seroprevalence as high $(\geq 90 \%$ by age 10 years); intermediate ( $\geq 50 \%$ by age 15 years, with $<90 \%$ by age 10 years); low ( $\geq 50 \%$ by age
30 years, with $<50 \%$ by age 15$)$ : and very low ( $<$ $50 \%$ by age 30 years) 1 . According to our seroprevalence results, the municipality of Campos dos Goytacazes presents a low endemic level for hepatitis A. Rates of anti-HAV seroprevalence were compared to those reported previously for population groups living in Southeastern Brazil $10,26,27,28$ even among those groups with higher incomes 29,30. Results are also in agreement with those described in the population-based survey conducted in Brazilian capital cities 16, in which the Southeast region of Brazil was found to be a low endemic area for hepatitis A.

Among the classical risk factors for HAV infection in developing countries investigated in this study, age, non-white skin color, crowding, educational level of the mother, and habit of swimming in rivers emerged as significant contributors to HAV seropositivity in Campos dos Goytacazes. Consistent with previous studies $10,27,29,31,32$, age was the most robust variable associated with the prevalence of anti-HAV antibodies. Logistic regression pointed to an increasing risk gradient as the age of the individuals increased. These data suggest that the risk of HAV infection is determined more by the increased exposure time of older individuals to circulating HAV.

Results of the final multilevel logistic regression model including variables putatively associated with HAV antibodies. Municipality of Campos dos Goytacazes, Rio de Janeiro State, Brazil, 2011-2012.

\begin{tabular}{|c|c|c|c|}
\hline Variable & OR & $95 \% \mathrm{Cl}$ & p-value \\
\hline \multicolumn{4}{|l|}{ Age group (years) } \\
\hline $1-4$ & 1.000 & - & - \\
\hline $5-9$ & 3.123 & $1.294-7.539$ & 0.0115 \\
\hline $10-14$ & 7.004 & $2.708-18.115$ & 0.0001 \\
\hline $15-19$ & 18.329 & $4.462-75.285$ & 0.0001 \\
\hline Skin color non-white & 2.486 & $1.410-4.383$ & 0.0017 \\
\hline Swimming in the river & 1.787 & $1.128-2.831$ & 0.0136 \\
\hline Persons in the household $>5$ & 2.714 & $1.687-4.367$ & 0.0000 \\
\hline \multicolumn{4}{|l|}{ Level of mother education } \\
\hline Illiterate & 1.000 & - & - \\
\hline Primary & 0.599 & $0.267-1.343$ & 0.2137 \\
\hline Secondary and higher & 0.327 & $0.131-0.812$ & 0.0162 \\
\hline Uncertain/Unknown & 0.873 & $0.295-2.584$ & 0.8062 \\
\hline \multicolumn{4}{|l|}{ Living area } \\
\hline Urban & 1.000 & - & - \\
\hline Suburban & 0.932 & $0.467-1.859$ & 0.8416 \\
\hline Rural & 1.281 & $0.701-2.341$ & 0.4212 \\
\hline
\end{tabular}

95\% $\mathrm{Cl}$ : 95\% confidence interval; HAV: hepatitis A virus; OR: odds ratio. 
Figure 2

Odds ratio (OR) determined by multivariate logistic regression analysis.

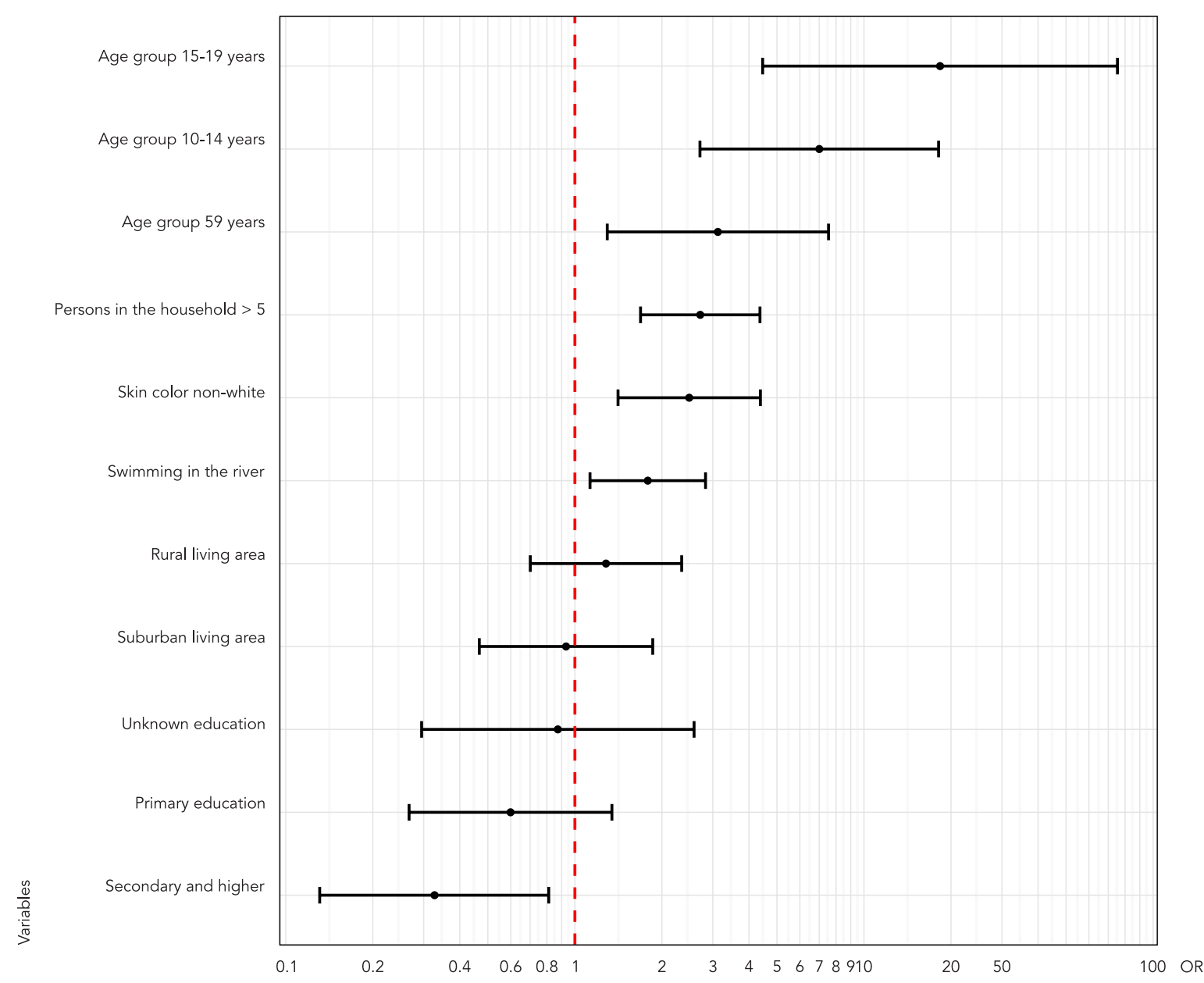

Note: that increasing age, number of persons in the household > 5, skin color non-white, swimming in the river, and level of maternal education (secondary or higher) were significant independent predictors of HAV seropositivity.

According to previous studies, non-white individuals were more likely to be immune to HAV, compared with white individuals 10,29. However, rather than related with the biology of racial differences, this result is probably associated with the increasing public health-related risks to which certain social groups such as blacks, women, slum dwellers and the homeless are exposed, which are mainly socio-economic issues 33,34 . Several racial inequality conditions were pointed out in studies with different objectives conducted among Brazilian populations. In a study comparing adult users of (private and public) oral healthcare services in the state of Minas Gerais, Pinto et al. 35 observed that dark-skinned black race/ color individuals were directly associated with the use of public healthcare services. Historically, underprivileged populations in Brazil tend to use public healthcare services 36 . The investigation of determinants of late stage diagnosis of cervical cancer showed that socioeconomic disparities in the country could be associated with this condition; women aged $\geq 50$, with black skin color, and of low educational levels were more likely to be diagnosed at advanced stage of cervical cancer ${ }^{37}$. Living conditions of the Brazilian black population result from unjust social, cultural and economic processes present in the history of the country ${ }^{36}$. The persistence of this social inequality over the years can be demonstrated by the 
precocity of deaths, the high rates of maternal and child mortality, high prevalence of chronic and infectious diseases, as well as high rates of urban violence that mainly affects the black population 36. Inequities are also evidenced between indigenous and non-indigenous populations in relation to diverse health indicators, such as rates of illness and deaths from contagious diseases. Results from the first National Survey of Indigenous People's Health and Nutrition conducted in Brazil revealed that health indicators of both indigenous women and children were shown to be worse than those documented for the Brazilian population as a whole, with important regional variations 38 .

Prevalence was also associated with increased number of family members, which has observed by other authors 4,10,29,39. Living in crowded settings especially under bad hygienic conditions favors hepatitis A transmission 40,41,42. Close personal contact creates a risk of infection in a crowded family because of decreased living area per individual 42 .

It is reported that increased family education levels are associated with a reduction in hepatitis A prevalence $4,10,39,42$. We also found a similar negative correlation between the seroprevalence rate and maternal education levels. The educational level of the mother influences knowledge of personal hygiene, since learning about hygiene is basically transmitted by mothers.

Prevalence of HAV antibodies was also associated with habits of swimming in rivers, as previously reported 4,27 . Contamination of surface waters with enteric viruses is a public health concern, especially if these surface waters are used for recreational purposes. Water has been identified as one of the main vehicles for HAV transmission that can occur during contact with contaminated surface water by feces, as well as consumption of contaminated water ${ }^{43}$. HAV has been isolated from surface waters which may be used for recreational purposes 44,45 and a number of HAV cases have been documented in association with the use of water for recreational purposes 46,47 .

Typically, the highest rates of anti-HAV prevalence are observed in socioeconomically disadvantaged populations. In fact, the prevalence of HAV infection could even be used as an index of the level of development of a given country 12 . However, it has been shown that the introduction of sanitary improvements is a major factor in changing the prevalence of HAV infection, even when the socioeconomic level of a given population remains low 9,10 . In the absence of public sanitary facilities, simplistic mechanisms of water and sewage disposal, such as artesian wells and septic cesspools are efficient for minimizing the chance of HAV infection 10. The low HAV seroprevalence in the municipality of Campos dos Goytacazes reflects a decreasing exposure to HAV among children and adolescents, associated with improved living conditions. In fact, although most participants were from a low socioeconomic status (87.9\%), the majority of them lived in households with access to piped water (77.1\%) and connected with a system for sewage disposal, whether a sewage system (57.9\%) or a septic cesspool (31.3\%). This profile was also demonstrated in other seroepidemological studies carried out with Brazilian communities from low socioeconomic levels living under adequate sanitary conditions 10,27 as well as in other developing countries that underwent improvements in hygiene, particularly in regions such as Latin America, the Middle East, and Southeast Asia. A decrease in the prevalence of HAV infection was observed by Afegbua et al. 48 in schoolchildren and adolescents in Kaduna, Nigeria, which was attributed to improvements in sanitation, water supply and living standards that were locally implemented in the last three decades. The HAV seroprevalence rate in Lebanon also decreased by $40 \%$ in children aged $1-5$ and by $85 \%$ in children aged 6-12 in 1982 to $10.5 \%$ and $27.7 \%$, respectively, in 200549.

The most important mode of hepatitis A control is by improvements in hygiene and sanitation conditions and in drinking water supply, which accompany socioeconomic progress. However, the implementation of better living standards without immunization against HAV infection creates an increasing pool of susceptible individuals with risk of infection by the virus that still circulates. Indeed, acute hepatitis A cases have been continuously reported in the county of Campos dos Goytacazes. According to data from the Brazilian Information System for Notifiable Diseases (SINAN), in the years 2006-2013 the municipality of Campos recorded a total of 301 cases of hepatitis A. HAV has been consistently detected in water samples for human consumption in other municipalities of the State of Rio de Janeiro (for example in the municipalities of Mangaratiba and Petrópolis) where hepatitis A outbreaks have occurred (Oliveira JM, personal communication). In the environmental sphere, HAV has contaminated many Brazilian aquatic ecosystems from large urban cities, mainly in Rio de Janeiro and São Paulo 50,51.

According to the WHO report on hepatitis A vaccines 1 , the populations in middle-income countries (such as those in Asia, Latin America, Eastern Europe, and the Middle East) may benefit the most from large-scale HAV vaccination 
programs. Hepatitis A vaccination was recently implemented (July 2014) in the Brazilian EPI, in a single dose scheme for children that are 1-2 years old 52. Several cost-effectiveness studies supported the ministerial decision. Sartori et al. 53 demonstrated that a universal immunization program would have a significant impact on disease epidemiology in all Brazilian regions, resulting in a $64 \%$ reduction in the number of cases of icteric hepatitis, $59 \%$ reduction in deaths for the disease and a $62 \%$ decrease in loss of life years nationwide. Zahdi et al. ${ }^{54}$ showed that for each dollar invested in the vaccine, a saving of 2.26 USD in treatment would be obtained.

In conclusion, the low anti-HAV antibody prevalence rate observed in children and adoles-

\section{Conflict of interests}

The authors declare that they have no competing interests.

\section{Contributors}

C. M. Kury participated in the study design and data analysis, collected the epidemiological data and samples, performed the serological analyses and wrote the manuscript. M. A. Pinto participated in the data analysis and critical revision of the manuscript. J. P. Silva performed the serological assays. O. G. Cruz participated in the study design and performed the statistical analysis. C. L. Vitral conceived the study, performed the serological assays, analyzed the data, wrote the manuscript, and edited the article. All authors read and approved the final manuscript. cents reflects a decreasing exposure to HAV infection among individuals living in this municipality of Southeastern Brazil. The reduced exposure to HAV could be associated with an increased standard of living due to improvements in sanitation. The introduction of HAV immunization before school admittance since 2011 in Campos dos Goytacazes will certainly represent an important complementary strategy for the control of hepatitis A, particularly among children who are now susceptible to HAV infection.

Further epidemiological studies should be carried out in the future in order to evaluate the impact that immunization will have on the epidemiology of hepatitis A in Brazil.

\section{Acknowledgments}

This work was supported by grants from the Rio de Janeiro State Research Foundation (FAPERJ E-26/ 110.278/2012 - APQ1). M. A. Pinto receive sênior research scholarships from the Brazilian National Research Council (CNPq). J. P. Silva was supported by a CNPq scholarship.

We would like to thank Marcus Miguel Haddad Kury, Claudio Luiz dos Santos Teixeira and Bruna Cirilli for the collection of epidemiological data and samples. We also would like to thank the inhabitants of the municipality of Campos dos Goytacazes for their enthusiastic participation in the study. 
1. WHO position paper on hepatitis A vaccines - June 2012. Wkly Epidemiol Rec 2012; 87:261-76.

2. Hendrickx G, Van Herck K, Vorsters A, Wiersma S, Shapiro C, Andrus JK, et al. Has the time come to control hepatitis A globally? Matching prevention to the changing epidemiology. J Viral Hepat 2008;15 Suppl 2:1-15

3. Mohd Hanafiah K, Jacobsen KH, Wiersma ST. Challenges to mapping the health risk of hepatitis A virus infection. Int J Health Geogr 2011; 10:57.

4. Ciaccia MC, Moreira RC, Ferraro AA, Lemos MF, Oba IT, Porta G. Epidemiological and serological aspects of hepatitis A among children and teenagers in the city of Santos: a cross-sectional study. São Paulo Med J 2012; 130:230-5.

5. Gonçalves AA, Oliveira LC. Seroprevalence of hepatitis A immunity among children and adolescents in two cities of the Triângulo Mineiro region, state of Minas Gerais, Brazil. Braz J Infect Dis 2012; 16:496-7.

6. Krebs LS, Ranieri TM, Kieling CO, Ferreira CT, da Silveira TR. Shifting susceptibility to hepatitis A among children and adolescents over the past decade. J Pediatr (Rio J.) 2011; 87:213-4.

7. Markus JR, Cruz CR, Maluf EMCP, Tahan TT, Hoffman MM. Seroprevalence of hepatitis A in children and adolescents. J Pediatr (Rio J.) 2011; 87:419-24.

8. Vitral CL, Gaspar AM, Souto FJ. Epidemiological pattern and mortality rates for hepatitis A in Brazil, 1980-2002 - a review. Mem Inst Oswaldo Cruz 2006; 101:119-27.

9. Vitral CL, Souto FJ, Gaspar AM. Changing epidemiology of hepatitis A in Brazil: reassessing immunization policy. J Viral Hepat 2008; 15 Suppl 2:22-5.

10. Vitral CL, Ospina FL, Artimos S, Melgaço JG, Cruz OG, Paula VS, et al. Declining prevalence of hepatitis A virus antibodies among children from low socioeconomic groups reinforces the need for the implementation of hepatitis A vaccination in Brazil. Mem Inst Oswaldo Cruz 2012; 107:652-8.

11. Clemens SA, Fonseca JC, Azevedo T, Cavalcanti A, Silveira TR, Castilho MC, et al. Soroprevalência para hepatite A e hepatite B em quatro centros no Brasil. Rev Soc Bras Med Trop 2000; 33:1-10.

12. Jacobsen KH, Wiersma ST. Hepatitis A virus seroprevalence by age and world region, 1990 and 2005. Vaccine 2010; 28:6653-7.

13. Secretaria de Vigilância Epidemiológica, Ministério da Saúde. Boletim epidemiológico - hepatites virais 2012. http://www.aids.gov.br/publica cao/2012/boletim_de_hepatites_virais_2012 (accessed on 27/Oct/2014).

14. Alencar Ximenes RA, Martelli CM, Merchán-Hamann E, Montarroyos UR, Braga MC, Lima ML, et al. Multilevel analysis of hepatitis A infection in children and adolescents: a household survey in the Northeast and Central-west regions of Brazil. Int J Epidemiol 2008; 37:852-61.

15. Ximenes RAA, Pereira LMB, Martelli CMT, Merchán-Hamann E, Stein AT, Figueiredo GM, et al. Methodology of a nationwide cross-sectional survey of prevalence and epidemiological patterns of hepatitis A, B and C infection in Brazil. Cad Saúde Pública 2010; 26:1693-704.
16. Secretaria de Vigilância Epidemiológica, Ministério da Saúde. Estudo de prevalência de base populacional das infecções pelos vírus das hepatites A, B e C nas capitais do Brasil. 2010. http://www. aids.gov.br/sites/default/files/anexos/publica cao/2010/50071/estudo_prevalencia_hepatites_ pdf_26830.pdf (accessed on 27/Oct/2014).

17. Ximenes RA, Martelli CM, Amaku M, Sartori AM, Soárez PC, Novaes HM, et al. Modelling the force of infection for hepatitis A in an urban populationbased survey: a comparison of transmission patterns in Brazilian macro-regions. PLoS One 2014; 9:e94622.

18. Santos DC, Martinho JM, Pacheco-Moreira LF, Araújo CC, Oliveira BC, Lago BV, et al. Fulminant hepatitis failure in adults and children from a Public Hospital in Rio de Janeiro, Brazil. Braz J Infect Dis 2009; 13:323-9.

19. Munné MS, Vladimirsky S, Moreiro R, Ciocca M, Cuarterolo M, Otegui L, et al. Molecular characterization of hepatitis A virus in children with fulminant hepatic failure in Argentina. Liver Int 2008; 28:47-53.

20. Bendre SV, Bavdekar AR, Bhave SA, Pandit AN, Chitambar SD, Arankalle VA. Fulminant hepatic failure: etiology, viral markers and outcome. Indian Pediatr 1999; 36:1107-12.

21. Kim YJ, Lee HS. Increasing incidence of hepatitis A in Korean adults. Intervirology 2010; 53:10-4.

22. Vizzotti C, González J, Gentile A, Rearte A, Ramonet M, Cañero-Velasco MC, et al. Impact of the single-dose immunization strategy against hepatitis A in Argentina. Pediatr Infect Dis J 2014; 33:84-8.

23. Secretaria de Vigilância em Saúde, Ministério da Saúde. 13a Expoepi: mostra nacional de experiências bem-sucedidas em epidemiologia, prevenção e controle de doenças 2013. http://bvsms. saude.gov.br/bvs/publicacoes/13_expoepi_mos tra_nacional_experiencias.pdf (accessed on 16/ Oct/2015).

24. Prefeitura Municipal de Campos dos Goytacazes. Portal Campos 2015. http://www.campos.rj.gov. br/exibirNoticia.php?id_noticia=27458 (accessed on 18/Aug/2015).

25. Instituto Trata Brasil. Ranking de saneamento. Resultados com base no SNIS 2012. http://www. tratabrasil.org.br/datafiles/estudos/ranking/ relatorio-completo-2014.pdf (accessed on 27/ Oct/2014).

26. Melgaço JG, Pinto MA, Rocha AM, Freire M, Gaspar LP, Lima SM, et al. The use of dried blood spots for assessing antibody response to hepatitis A virus after natural infection and vaccination. J Med Virol 2011; 83:208-17.

27. Vitral CL, Yoshida CF, Lemos ER, Teixeira CS, Gaspar AM. Age-specific prevalence of antibodies to hepatitis A in children and adolescents from Rio de Janeiro, Brazil, 1978 and 1995. Relationship of prevalence to environmental factors. Mem Inst Oswaldo Cruz 1998; 93:1-5.

28. Vitral CL, Yoshida CFT, Teixeira CR, Gaspar AMC. Seroprevalence of hepatitis A in health care students from a public university of Rio de Janeiro, Brazil. Rev Microbiol 1998; 29:58-60. 
29. Zago-Gomes MP, Stantolin GC, Perazzio S, Aikawa KH, Gonçalves CS, Pereira FE. Prevalence of antihepatits A antibodies in children of different socioeconomic conditions in Vila Velha, ES. Rev Soc Bras Med Trop 2005; 38:285-9.

30. Dinelli MI, Fisberg M, Moraes-Pinto MI. Anti-hepatitis A virus frequency in adolescents at an outpatient clinic in São Paulo, Brazil. Rev Inst Med Trop São Paulo 2006; 48:43-4.

31. Almeida D, Tavares-Neto J, Vitvitski L, Almeida A, Mello C, Santana D, et al. Serological markers of hepatitis A, B and C viruses in rural communities of the semiarid Brazilian northeast. Braz J Infect Dis 2006; 10:317-21.

32. Vitral CL, Silva-Nunes M, Pinto MA, Oliveira JM, Gaspar AM, Pereira RC, et al. Hepatitis A and E seroprevalence and associated risk factors: a community-based cross-sectional survey in rural Amazonia. BMC Infect Dis 2014; 14:458.

33. Khan MM, Kraemer A. Socio-economic factors explain differences in public health-related variables among women in Bangladesh: a cross-sectional study. BMC Public Health 2008; 8:254.

34. Hennessey KA, Bangsberg DR, Weinbaum C, Hahn JA. Hepatitis A seroprevalence and risk factors among homeless adults in San Francisco: should homelessness be included in the risk-based strategy for vaccination? Public Health Rep 2009; 124:813-7.

35. Pinto RS, Abreu MH, Vargas AM. Comparing adult users of public and private dental services in the State of Minas Gerais, Brazil. BMC Oral Health 2014; 14:100.

36. Ministério da Saúde. Política Nacional de Saúde Integral da População Negra: uma política para o SUS. http://bvsms.saude.gov.br/bvs/publicacoes/ politica_nacional_saude_integral_populacao.pdf (accessed on 16/Oct/2015).

37. Thuler LC, Aguiar SS, Bergmann A. Determinantes do diagnóstico em estadio avançado do câncer do colo do útero no Brasil. Rev Bras Ginecol Obstet 2014; 36:237-43.

38. Coimbra CE Jr, Santos RV, Welch JR, Cardoso AM, Souza MC, Garnelo L, et al. The First National Survey of Indigenous People's Health and Nutrition in Brazil: rationale, methodology, and overview of results. BMC Public Health 2013; 13:52.

39. Gomes MAC, Ferreira ASP, Silva AAM, Souza ER. Hepatitis A: seroprevalence and associated factors among schoolchildren of São Luís (MA), Brazil. Rev Bras Epidemiol 2011; 14:548-55.

40. Stroffolini T, Chiaramonte M, Franco E, Rapicetta M, De Mattia D, Mura I, et al. Baseline seroepidemiology of hepatitis A virus infection among children and teenagers in Italy. Infection 1991; 19:97-100.

41. Almeida LM, Werneck GL, Cairncross S, Coeli CM, Costa MC, Coletty PE. The epidemiology of hepatitis A in Rio de Janeiro: environmental and domestic risk factors. Epidemiol Infect 2001; 127:327-33.
42. Ceran N, Yüksel Kocdogan F, Mert D, Erdem I, Dede B, Adaleti R, et al. Hepatitis A seroprevalence in children and young adults in Istanbul, Turkey: seroprevalence change and associated factors. J Viral Hepat 2012; 19:72-6.

43. Koff RS. Seroepidemiology of hepatitis A in the United States. J Infect Dis 1995; 171 Suppl 1:S19-23.

44. Fongaro G, Nascimento MA, Viancelli A, Tonetta D, Petrucio MM, Barardi CR. Surveillance of human viral contamination and physicochemical profiles in a surface water lagoon. Water Sci Technol 2012; 66:2682-7.

45. Rigotto C, Victoria M, Moresco V, Kolesnikovas CK, Corrêa AA, Souza DS, et al. Assessment of adenovirus, hepatitis A virus and rotavirus presence in environmental samples in Florianopolis, South Brazil. J Appl Microbiol 2010; 109:1979-87.

46. Garin D, Fuchs F, Crance JM, Rouby Y, Chapalain JC, Lamarque D, et al. Exposure to enteroviruses and hepatitis A virus among divers in environmental waters in France, first biological and serological survey of a controlled cohort. Epidemiol Infect 1994; 113:541-9.

47. Taylor MB, Becker PJ, Janse van Rensburg E, Harris B, Bailey IW, Grabow WOK. A serosurvey of waterborne pathogens amongst canoeists in South Africa. Epidemiol Infect 1995; 115:299-307.

48. Afegbua SL, Bugaje MA, Ahmad AA. Seroprevalence of hepatitis A virus infection among schoolchildren and adolescents in Kaduna, Nigeria. Trans R Soc Trop Med Hyg 2013; 107:627-30.

49. Sacy RG, Haddad M, Baasiri G, Khoriati A, Gerbaka BJ, Abu-Elyazeed R. Hepatitis A in Lebanon: a changing epidemiological pattern. Am J Trop Med Hyg 2005; 73:453-6.

50. Miagostovich MP, Guimarães FR, Vieira CB, Fumian TM, Gama NP, Victoria M, et al. Assessment of water quality in a border region between the Atlantic forest and an urbanised area in Rio de Janeiro, Brazil. Food Environ Virol 2014; 6:110-5.

51. Vieira C, Mendes A, Oliveira J, Gaspar A, Leite J, Miagostovich M. Vírus entéricos na Lagoa Rodrigo de Freitas. Oecologia Australis 2012; 16:540-65.

52. Secretaria de Vigilância em Saúde, Ministério da Saúde. Informe técnico da introdução da vacina adsorvida hepatite A (inativada). http://www. sgc.goias.gov.br/upload/arquivos/2014-02/infor me-tec-vacina-hepatite-a.pdf (accessed on 27/ Out/2014).

53. Sartori AM, de Soárez PC, Novaes HM, Amaku M, de Azevedo RS, Moreira RC, et al. Cost-effectiveness analysis of universal childhood hepatitis A vaccination in Brazil: regional analyses according to the endemic context. Vaccine 2012; 30:7489-97.

54. Zahdi MR, Maluf I, Maluf EM. Hepatitis A: the costs and benefits of the disease prevention by vaccine, Paraná, Brazil. Braz J Infect Dis 2009; 13:257-61. 


\section{Resumo}

Estudo do corte transversal, realizado entre agosto de 2011 e julho de 2012 em Campos dos Goytacazes, Rio de Janeiro, Brasil. Amostras de sangue capilar em papel de filtro foram coletadas de 919 indivíduos com idade entre 1 e 19 anos e testadas para anticorpos para o vírus da hepatite A (anti-HAV). A prevalência total foi de 20,7\% e 94,7\% das crianças abaixo de 5 anos foi suscetível a infecção pelo HAV. A prevalência de anti-HAV aumentou com a idade, alcançando 33,3\% entre indivíduos com 15 a 19 anos, caracterizando este município com um nível baixo de endemicidade para hepatite A. Idade, cor da pele não-branca, hábito de nadar no rio e número de moradores na residência acima de 5 foram associados com o aumento de chance de ser positivo para anti-HAV. O nível educacional materno (médio ou superior) foi considerado como fator de proteção para a infecção pelo HAV. Os dados obtidos mostraram que uma grande parte das crianças de Campos dos Goytacazes estava sob risco de infecção pelo HAV, o que deve ser minimizado com o programa de vacinação contra hepatite A implantado em 2011 no município.

Hepatite A; Vacinas Contra Hepatite A; Estudos Soroepidemiológicos

\section{Resumen}

Estudio de corte transversal, realizado entre agosto de 2011 y julio de 2012 en Campos dos Goytacazes, Río de Janeiro, Brasil. Se recogieron muestras de sangre capilar en papel de filtro de 919 individuos con una edad entre 1 y 19 años y testadas para anticuerpos del virus de la hepatitis A (anti-HAV). La prevalencia total fue de un 20,7\% y un 94,7\% de los niños por debajo de los 5 años fue susceptible a la infección por el HAV. La prevalencia de anti-HAV aumentó con la edad, alcanzando un 33,3\% entre individuos con 15 a 19 años, caracterizando este municipio con un nivel bajo de endemicidad para la hepatitis A. Edad, color de piel noblanca, hábito de nadar en el río y un número de ocupantes en la residencia de más de 5 se asociaron con el aumento de oportunidad de ser positivo para antiHAV. El nivel educacional materno (medio o superior) se consideró como un factor de protección para la infección por el HAV. Los datos obtenidos mostraron que una gran parte de los niños de Campos dos Goytacazes estaba bajo riesgo de infección por el HAV, lo que debe ser minimizado con el programa de vacunación contra la hepatitis A implantado en 2011 en el municipio.

Hepatitis A; Vacunas Contra la Hepatitis A; Estudios Seroepidemiológicos
Submitted on $24 /$ Nov/2014

Final version resubmitted on 19/Jan/2016

Approved on 23/Feb/2016 